ISSN 0258-7122 (Print), 2408-8293 (Online)

Bangladesh J. Agril. Res. 41(3): 491-505, September 2016

\title{
ADOPTION OF WHEAT VARIETIES IN BANGLADESH: EXPERT ELICITATION APPROACH
}

\author{
M. A. RASHID ${ }^{1}$ AND TANVIR M. B. HOSSAIN ${ }^{2}$
}

\begin{abstract}
The study was undertaken to find out variety wise adoption rate of wheat in Bangladesh through expert elicitation procedure. Many varieties have been developed by Wheat Research Centre (WRC) but in details of varietal information and adoption information database was not developed which is very important and valuable for the scientist and policy planner. This study through expert elicitation for constructing detail varietal development and adoption database is timely and necessary for the research institute. From all over the Bangladesh 14 experts was invited to share their valuable knowledge and experience on wheat cultivation and adoption in the country. The average age of the experts were $54 \mathrm{yrs}$ and average experience on wheat adoption was 22.65 yrs. The wheat expert informed that 13 major varieties are adopted by the farmers in the recent year(2013-14). Among those varieties, BARI Gom 24 (Prodip) covered highest cultivated area (186026 ha) which shared $41.03 \%$ of total wheat cultivated area. BARI Gom 21 (Shatabdi), BARI Gom 26 and BARI Gom 23 (Bijoy) ranked 2nd, 3rd and 4th position according to the share of cultivated area covered. The seed production information showed that BADC the only wheat seed producer supplied $24912.60 \mathrm{mt}$ of wheat seed in the year 2013-14. The trend of seed production by different wheat variety revealed that over the period 2010-14, the seed production of BARI Gom 24 (Prodip) increased and BARI Gom 21 (Shatabdi) decreased. Increased seed production trend of Prodip variety leaded to highest adopted area of that variety. The main reason behind highest adopted area of Prodip variety was it's very attractive attributes like high yield, big spike, large grain and lodging tolerance character. Although the Prodip covered highest area but other newly developed variety like BARI Gom 25, BARI Gom 26, BARI Gom 27 and BARI Gom 28 were the most promising varieties which showed increasing adoption path among the expert. These varieties have very good potentiality due to having short duration, tolerance to terminal heat stress, tolerant to salinity and lodging attributes. Satisfying higher demand for wheat consumption and ensuring food security through providing alternative to rice are the major concerning issue of the policy planner and the scientist. Therefore, the study have been undertaken to fulfill this issues.
\end{abstract}

Keywords: economics, expert elicitation, varietal adoption.

\footnotetext{
${ }^{1}$ Principal Scientific Officer and ${ }^{2}$ Senior Scientific Officer, Agricultural Economics Division, Bangladesh Agricultural Research Institute (BARI), Gazipur, Bangladesh.
} 


\section{Introduction and background}

\subsection{Position of wheat and change over time}

Wheat is third highest growing cereals on the basis of cultivation area. Farmers of Bangladesh cultivated wheat on 453421 ha of cultivated land and produced $1375270 \mathrm{mt}$ of wheat in the year 2014 (Fig.1). The average yield of wheat was $3.03 \mathrm{mt} / \mathrm{ha}$. Wheat cultivation area shared $4.77 \%$ of net cropped area and $2.5 \%$ of total cropped area of Bangladesh in year 2010-11. Irrigated wheat cultivated area covered 3,46,558 ac of land which was $5.06 \%$ of total irrigated area of Bangladesh in the year 2010-11. The average per capita per day intake of rice was $416 \mathrm{gm}$ and wheat was $26 \mathrm{gm}$. Wheat contributes $2.6 \%$ of per capita per day total consumption of Bangladesh people. Wheat consumption was increased by 2.14 times in 2010 compare to consumption amount of the year 2005 (BBS, 2010). Wheat grows in the sub-tropic and tropic region of Bangladesh. In that region the mean temperature during growing period (November to April) of wheat range from $18.8{ }^{\circ} \mathrm{C}$ to $25.3{ }^{\circ} \mathrm{C}$. Prior to $1975-76$, wheat was grown sporadically and was almost an unknown crop in Bangladesh (Banglapedia, 2006). Between 1970-71 and 1980-81, the cropped area under wheat jumped from 0.126 million ha to 0.591 million ha and production rose 10-fold from 0.11 million tons to 1.07 million tons, a $24.93 \%$ annual mean growth rate (BARI, 2010).

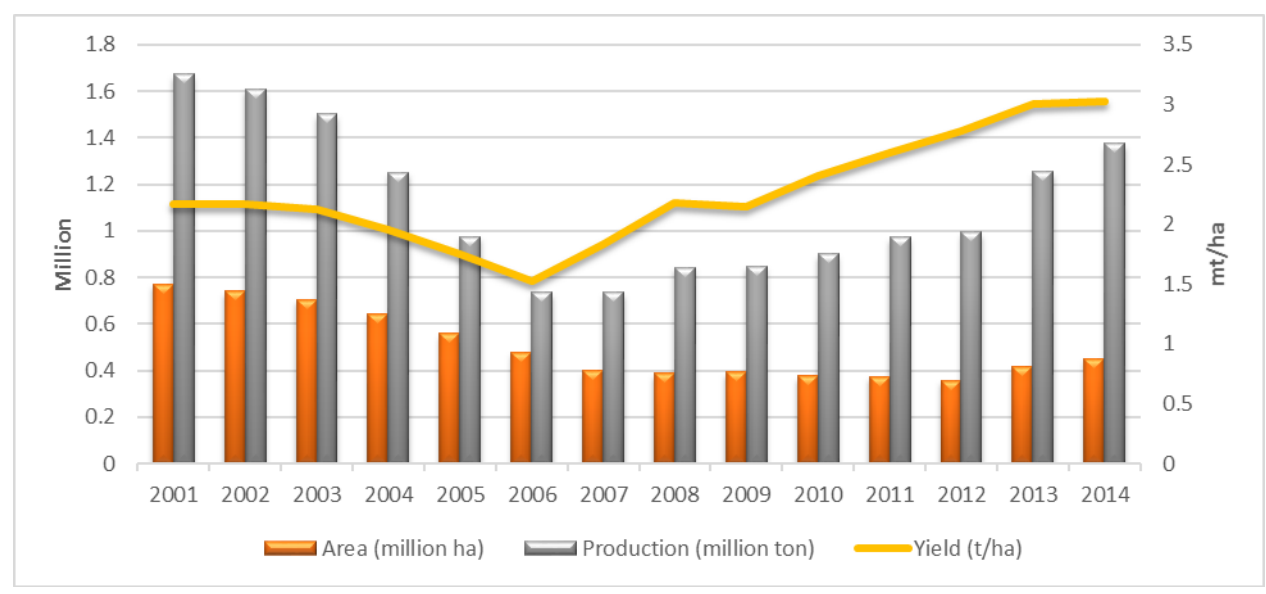

Fig.1. Area, production and yield of wheat cultivation in the period 2001-14.

\section{Reason of change in consumption}

Even though most of the wheat varieties developed by the researcher in Bangladesh are high yielding varieties, but due to slow increase of cultivation area and production those wheat varieties did not keep pace sufficiently to match with the increasing demand of wheat created by increased population. The 
changing habit of cereal consumption also helped to increase demand for wheat compare to rice (WRC, 2009). In this situation, to meet the demand of an increasing population and to secure future food security, the government of Bangladesh imported more wheat between 2008 and 2011.

\section{Import history}

Bangladesh is net importer of wheat and the country imported wheat 31,12,314 mt (Fig-2) in the year 2011 (FAOStat, 2014) and from the national statistical source the imported wheat was worth of Tk. 86,46,84,88,000 in the year 2010-11 (BBS, 2011). Wheat import increased with growth rate $11.52 \%$ per year over the period 2007-11. After the time of independence (1971), Bangladesh had become highly dependent on wheat imports while dietary preferences were changing such that wheat was becoming a highly desirable food supplement to rice. Wheat also accounted for the greatest bulk of imported food grains, exceeding 1 million tons annually and rising above 1.8 million tons in 1984, 1985 and 1987 (Index Mundi, $2012 a$ ). The great bulk of wheat importation is financed under aid programmes of the USA, the European Union and the World Food Programme (Index Mundi, 2012b). A 3-year (2008-09 to 2010-11) examination by O'Brien (2011) indicated that Bangladesh imported 3.1 million metric tons of wheat each year to ensure local demand.

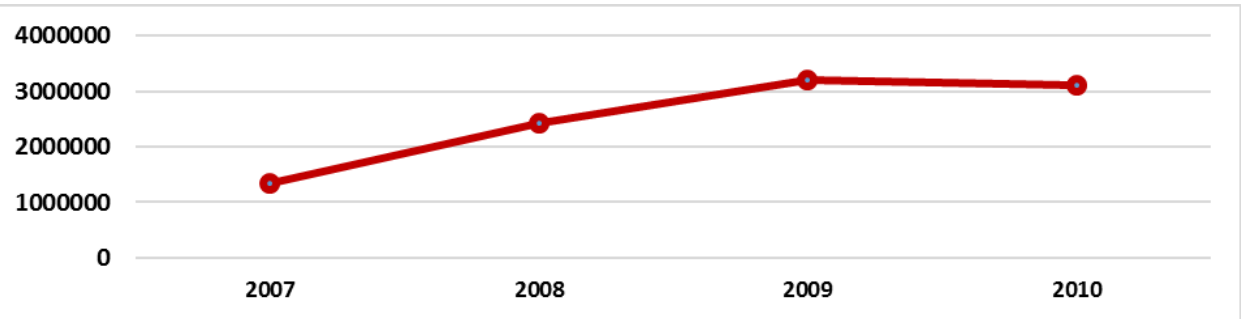

Fig.2. Trend line of wheat import in the period 2007-10.

\section{Regional status and history of wheat cultivation}

Wheat cultivation area is grouped by zone on the basis intensive growing districts. Highest wheat growing zone in the year 2011-12 was Rangpur zone (62.8\%) followed by Rajshahi (16.96\%), Jessore (8\%), Barisal (7.98\%) and others $(4.26 \%)$. The trend analysis revealed changing scenario of wheat cultivation area, production and yield of the different zone

Wheat cultivation in Bangladesh within the period 2007-12 is grouped into 5 regions. Bangladesh experienced increased wheat cultivation area by $7.48 \%$ per annum within the period 2007-12. With per year change rate, wheat cultivation area has been increased at Rajshahi (0.28\%), Rangpur (18.53\%), and Barisal $(2.76 \%)$ region and decreased at Jessore zone $(-1.4 \%)$. The large number of 
growth rate in those regions helped to increase wheat cultivation area in Bangladesh. Increased wheat production (mt) per year was observed at Rajshahi (7.33\%), Rangpur (3.85\%), Jessore (6.69\%), and Barisal (13.37\%) regions. In spite of having negative growth rate in other zone the country as whole achieved increase production $(5.57 \%$ ) per year with in that period 2007-12.

The wheat cultivation area and production didn't kept pace with positive relation. Highest rate of wheat yield (mt/ha) growth was observed of Barisal (10.62\%), Jessore $(8.38 \%)$ and Rajshahi $(7.05 \%)$ zone. Although, there is an increase and decrease trend of yield among the zones. But Bangladesh as a whole couldn't manage to increase yield per year (-1.9\%) with in the period 2007-12.

\subsection{Background of introducing wheat research in Bangladesh}

Wheat breeding research started in Bangladesh after the liberation war. The 'Noori 70', 'Balaka' and 'Doel' were first varieties developed by the scientists of BARI with the support of CIMMYT. The variety Noori 70 was developed in the year 1976 and 'Balaka' and 'Doel' were developed in the year 1980. In the initial stages of wheat growing in Bangladesh, several Mexican varieties, especially 'Sonora 64' and 'Kalyansona', were successfully introduced in collaboration with the International Maize and Wheat Improvement Center (CIMMYT). However, the release of 'Sonalika' created a true breakthrough in wheat production in the year 1972. This fast maturing and high-yielding variety (yield = 2 tons $\mathrm{ha}^{-1}$ ) became very popular among wheat growers and adapted well to different production environments, and was adopted in $80 \%$ of the wheat area by the early 1980s (WRC, 2009). In 1983, the Wheat Research Centre (WRC) of Bangladesh Agricultural Research Institute (BARI), released four more highyielding (yield $=2-3$ tons ha $^{-1}$ ) varieties ('Ananda', 'Kanchan', 'Barkat', and 'Akbar'). Among these, 'Kanchan' proved particularly adaptable and gradually replaced 'Sonalika' to became the predominant variety in Bangladesh by the early 1990s. Two other high-yielding varieties, 'Aghrani' and 'Protiva', were recommended by the Bangladesh National Seed Board in 1987 and 1993, respectively. These varieties were more responsive to a wider range of weather conditions as well as crop management practices such as fertilizers, irrigation and intercultural operations. Therefore, by the mid-1990s, adoption of high-yielding varieties were almost $100 \%$, thereby increasing wheat productivity substantially.

However, breeding efforts to develop high-yielding varieties still continued. Several more high-yielding varieties were developed. These included 'BARI Gom 19' ('Sourav') and 'BARI Gom 20' ('Gourab') released in 1998; 'BARI Gom 21' ('Shatabdi') in 2000; 'BARI Gom 22' ('Sufi'), 'BARI Gom 23' ('Bijoy') and 'BARI Gom 24' ('Prodip') in 2005 (Pandit et al., 2011); and 'BARI Gom 25' and 'BARI Gom 26' released in 2010 (BARI, 2012b). In 2012, two varieties, 'BARI Gom 27' and 'BARI Gom 28', were released and also in 
2014, another two more varieties, 'BARI Gom 29' and 'BARI Gom 30' were released.

\subsection{Statement of the problem}

BARI has released good number of high yielding varieties and improved management technologies of wheat crop. The Department of Agricultural Extension (DAE) has been involved in developmental programs for the technology transfer of this crop through its countrywide networks. This initiatives make the productivity growth of wheat increasing to a great extent. This impressive information indicates the immediate need of strengthening the current efforts of improved variety adoption at farm level. Although the released varieties have been found to be suitable for farmers, for various unknown reasons, a large number of farmers throughout the country are still reluctant to adopt these improved varieties that need to be evaluated properly. Since many farmers have not adopted these varieties, the level of wheat production remains far below of its potential.

With the detailed adoption information, the concern authority and agencies can formulate appropriate policy for the development of wheat crop across the country. Again, potential adoption of the improved varieties would generate employment and additional income for the rural poor and save foreign exchange through producing more of this crop utilizing fallow and under used lands in the country. Therefore, nationally representative and up-to-date data and information on the adoption of wheat cultivation are lacking in Bangladesh. This information could be useful for both government and donor agencies in investing more on wheat improvement programs in Bangladesh.

\subsection{Objectives of the study}

i) To document and process on varietal release at the national level

ii) To find out variety wise adoption rate of wheat in Bangladesh and

iii) To suggest policy implication from the findings

\section{Methodology}

\subsection{Data and data sources}

The main approach is to assemble relevant information and data of most recent year from multiple sources. This study collected time series data from national data sources i.e Bangladesh Bureau of Statistics, Department of Agricultural Extension. This study heavily collected for varietal development information from Wheat Research Centre (WRC), of Bangladesh Agricultural Research Institute. The collected varietal information were sourced from different annual research report of WRC and BARI, Handbook of BARI developed crop varieties 
and technologies. The authors of this study gathered very valuable information from scientist consultation and expert elicitation (EE) workshop.

\subsection{Details of experts}

A panel of knowledgeable experts about the adoption of wheat cultivars in the zones (ecosystem, season or administrative zone) was formed. The expert panel consisted of 14 experts including scientists (breeders, agronomists, and agricultural economists), extension workers, seed producers \& traders, think tank and farmers. The expert informed about wheat production systems in the region as well as at national level. Among the experts, $35.7 \%$ were from different national agricultural research institutions (Table 2.1).

Table 2.1. Experts involved in elicitation for wheat cultivation and production workshop

\begin{tabular}{l|c|c|c}
\hline \multicolumn{1}{c}{$\begin{array}{c}\text { Discipline of } \\
\text { experts }\end{array}$} & $\begin{array}{c}\text { No. of experts by } \\
\text { discipline }\end{array}$ & $\begin{array}{c}\text { No of experts from } \\
\text { NARS }\end{array}$ & $\begin{array}{c}\text { No of experts from non } \\
\text { NARS }\end{array}$ \\
\hline Scientist & 5 & 5 & - \\
Extension & 3 & - & 3 \\
Seed producer & 1 & - & 1 \\
Think tank & 3 & - & 3 \\
Farmers & 2 & - & 2 \\
Total & 14 & 5 & 9 \\
\hline
\end{tabular}

Source: Expert elicitation workshop, 2014.

Wheat is grown all over the country sporadically. In spite of that there are some districts where wheat cultivation share is significantly large. Higher wheat cultivation shared district were grouped in to four zones i.e Rajshahi, Rangpur, Jessore and Barisal (Table-2.2). These four zones covered 94\% of total wheat cultivation area of Bangladesh.

Table 2.2. Zone wise gross cropped areas and production of wheat in Bangladesh in the year 2014

\begin{tabular}{lc|c|c|c}
\hline \multicolumn{1}{c|}{ Zone } & Cultivated Area (ha) & Cultivated Area (\%) & $\begin{array}{c}\text { Production } \\
(\mathrm{MT})\end{array}$ & Yield (t/ha) \\
\hline Rajshahi Zone & 166782 & 36.78 & 539967 & 3.24 \\
Rangpur Zone & 124921 & 27.55 & 365873 & 2.93 \\
Jessore Zone & 63417 & 13.99 & 186389 & 2.94 \\
Barisal Zone & 71136 & 15.69 & 205838 & 2.89 \\
Other zone & 27165 & 5.99 & 77203 & 2.84 \\
Total & 453421 & 100.00 & 1375270 & 3.03 \\
\hline
\end{tabular}

Source: DAE, 2014. 


\section{Results and Discussion}

\subsection{More details about experts}

Age of expert plays an important role to share knowledge regarding the varietal adoption in EE workshop. Average age of expert was $54 \mathrm{yrs}$ old and the range of expert's age was from 44 yrs to 72 yrs. The expert had $22.65 \mathrm{yrs}$ of experience on crop and the range of expert's experience year was from 3.5 yrs to 48 yrs. The maximum years of experiences in present institute was 45 yrs and minimum was 3 yrs in the EE workshop. The average year of experience of expert in present institute was 19.25 yrs (Table 3.1).

Table 3.1. Quantification of expert's characteristics

\begin{tabular}{lcccc}
\hline Expert characteristics & Mean & Min & Max \\
\hline Age (years) & 54 & 44 & 72 \\
Years of experience on crop & 22.65 & 3.5 & 48 \\
Years of experience in present & 19.25 & 3 & 45 \\
institute & & & \\
\hline
\end{tabular}

Source: Expert elicitation workshop, 2014.

Table 3.2. Number of varieties developed in different period

\begin{tabular}{l|c|c}
\hline Period & Total varieties listed in data set 1 & No. of MV's \\
\hline Pre 1965 & - & - \\
$1965-1970$ & 2 & 2 \\
$1971-1975$ & 6 & 6 \\
$1976-1980$ & 4 & 4 \\
$1981-1985$ & 4 & 4 \\
$1986-1990$ & 4 & 4 \\
$1991-1995$ & 2 & 2 \\
$1996-2000$ & 8 & 8 \\
$2001-2005$ & 4 & 4 \\
$2006-10$ & 2 & 2 \\
2010 till now & 6 & 6 \\
Total & 40 & 40 \\
\hline
\end{tabular}

Source: BARI, 2010-12.

\subsection{Trends in varietal release}

By the time of independence (1971), Bangladesh had become highly dependent on wheat imports while dietary preferences were changing such that wheat was becoming a highly desirable food supplement to rice. In the initial stages of 
wheat growing in Bangladesh, the release of 'Sonalika' in 1972 created a true breakthrough in wheat production. Between 1971-75 and 1986-1990 BARI has developed and released 18 modern varieties of wheat in Bangladesh with the collaboration of CIMMYT (Table 3.2). By the mid-1990s to till now, adoption of high-yielding varieties was almost $100 \%$, thereby increasing wheat productivity substantially. However, breeding efforts to develop high-yielding varieties still continued. Several more high-yielding varieties were developed by BARI.

Seed Certification Agency of Ministry of Agriculture officially releases variety developed by public, private and NGO. In the Table-3.3, it is observed that $83 \%$ of variety used by the farmers were officially released variety. The variety developed by the NARS or together with CGAIR, $100 \%$ of them are improved variety. Among the improved or modern varieties (40) of wheat, the top most contributor was NARS $(80 \%)$ of the total contribution followed by CGIAR $(47.5 \%)$ and private sector $(15 \%)$.

Table 3.3. Share of contribution and linkage of different organization in varietal development

\begin{tabular}{c|c|c|c|c}
\hline Crop & $\begin{array}{c}\text { Total number } \\
\text { of varieties }\end{array}$ & $\begin{array}{c}\text { Number of } \\
\text { varieties linked } \\
\text { with CGIAR }\end{array}$ & $\begin{array}{c}\text { Number of } \\
\text { varieties linked } \\
\text { with NARS }\end{array}$ & $\begin{array}{c}\text { Number of varieties linked } \\
\text { with Private Sector } \\
\text { companies/ institutions }\end{array}$ \\
\hline Wheat & 40 & $19(47.5 \%)$ & $34(85 \%)$ & $6(15 \%)$ \\
\hline
\end{tabular}

Source: Own calculation.

Table 3.4. Number of varieties linked with CGIAR, NARS and Private Seed Companies

\begin{tabular}{l|c|c|c|c}
\hline \multicolumn{1}{c|}{ Period } & $\begin{array}{c}\text { Total } \\
\text { MV's }\end{array}$ & $\begin{array}{c}\text { Number of } \\
\text { varieties linked } \\
\text { with CGIAR }\end{array}$ & $\begin{array}{c}\text { Number of } \\
\text { varieties linked } \\
\text { with NARS }\end{array}$ & $\begin{array}{c}\text { Number of varieties } \\
\text { linked with Private Sector } \\
\text { companies/ institutions }\end{array}$ \\
\hline Pre 1965 & - & - & - & - \\
$1965-1970$ & 2 & 1 & 2 & 1 \\
$1971-1975$ & 6 & 5 & 6 & - \\
$1976-1980$ & 4 & 2 & 3 & 1 \\
$1981-1985$ & 4 & 3 & 4 & 1 \\
$1986-1990$ & 4 & 2 & 4 & 2 \\
$1991-1995$ & 2 & 1 & 2 & - \\
$1996-2000$ & 8 & 3 & 3 & - \\
$2001-2005$ & 4 & - & 3 & - \\
$2006-2010$ & 2 & - & 2 & - \\
2011 till now & 4 & 2 & 4 & 6 \\
Total & 40 & 19 & 34 & - \\
\hline
\end{tabular}

Source: BARI, 2010-12. 


\section{By time and source}

Among the modern varieties (40), CGIAR was the key role player (19) to develop wheat varieties during 1965-2014 followed by NARS (34) and private sector (6) in Bangladesh (Table-3.4).

\subsection{Trends in varietal adoption}

An attempt was made to assess the level of adoption of wheat variety in terms of area cultivated by farmers adopted at farm level. The level of adoption of wheat variety was mostly depended on the dissemination process used by BARI in association with the DAE. The scientists of BARI has been developed and disseminated 40 wheat varieties to the farmers since 1973. The finding of the EE workshop revealed that the farmers adopted wheat varieties such as BARI Gom 24 (Prodip), BARI Gom 21 (Shatabdi), BARI Gom 26, BARI Gom 23 (Bijoy), BARI Gom 25, BARI Gom 19 (Sourav), BARI Gom 18 (Protiva), and BARI Gom 27 etc. Among those adopted varieties, BARI Gom 24 (Prodip) was highly adopted variety (41.03\%) followed by Shatabdi (24.97\%), BARI Gom 26 (11.43\%), Bijoy (11.06\%) and BARI Gom 25 (4.45\%). Others varieties such as Sourav, Protiva, and BARI Gom 27 etc. occupied $7.07 \%$ of the total wheat areas in Bangladesh (Table 3.5).

Table 3.5. Adoption area and share of area identified by the expert

\begin{tabular}{lcc}
\hline $\begin{array}{c}\text { List top Modern Variety (MV) } \\
\text { as identified in EE }\end{array}$ & $\begin{array}{c}\text { Total country/ domain } \\
\text { cropped/ net sown area (ha) }\end{array}$ & $\begin{array}{c}\text { \% Area adopted under the } \\
\text { variety (ha) by EE }\end{array}$ \\
\hline BARI Gom 24 (Prodip) & 186026 & 41.03 \\
BARI Gom 21 (Shatabdi) & 113221 & 24.97 \\
BARI Gom 26 & 51814 & 11.43 \\
BARI Gom 23 (Bijoy) & 50170 & 11.06 \\
BARI Gom 25 & 20165 & 4.45 \\
BARI Gom 19 (Sourav) & 8175 & 1.80 \\
BARI Gom 18 (Protiva) & 5160 & 1.14 \\
BARI Gom 27 & 4938 & 1.09 \\
Kanchan & 3627 & 0.80 \\
BARI Gom 28 & 3249 & 0.72 \\
BARI Gom 20 (Gourav) & 2802 & 0.62 \\
Others & 2135 & 0.47 \\
BARI Gom 22 (Sufi) & 1519 & 0.34 \\
Inkilab & 419 & 0.09 \\
\hline
\end{tabular}

Source: Expert elicitation workshop, 2014. 


\subsection{Different from the adoption statistics seen in literature}

There is no detail wheat varietal adoption level study in Bangladesh. A very recent study conducted by WRC (2014) revealed the adoption level information of wheat varieties in the Bangladesh. The study showed that BARI Gom 24 (Prodip) is the dominant variety occupied across the country which covered $39 \%$ of total wheat areas (Table 3.6). This results supported by the EE workshop results but there was a little bit differences (2.03). BARI released other improved wheat variety BARI Gom 21 (Shatabdi) covered 35\% of total wheat area which was much higher differences $(-10.03)$ than the EE workshop results due to that adoption rate was for the some specific areas results. Same scenario was observed in case BARI Gom 23 (Bijoy). Another improved variety BARI Gom 26 covered $12 \%$ of the total wheat areas which was more or less same $(-0.57)$ to the EE workshop results.

Table 3.6. Adoption area and their difference with other sources

\begin{tabular}{l|c|c|c}
\hline $\begin{array}{c}\text { List top MV variety as } \\
\text { identified in EE }\end{array}$ & $\begin{array}{c}\text { \% Area adopted } \\
\text { under the } \\
\text { variety (ha) by } \\
\text { EE }\end{array}$ & $\begin{array}{c}\text { \% Area adopted under } \\
\text { the variety (ha) as seen in } \\
\text { literature/ national } \\
\text { survey/ other source }\end{array}$ & $\begin{array}{c}\text { \% difference } \\
\text { between the two }\end{array}$ \\
\hline Kanchan & 0.80 & - & - \\
BARI Gom 18 (Protiva) & 1.14 & - & - \\
BARI Gom 19 (Sourav) & 1.80 & - & - \\
BARI Gom 20 (Gourav) & 0.62 & - & - \\
Inkilab & 0.09 & - & -10.03 \\
BARI Gom 21 (Shatabdi) & 24.97 & 35.00 & - \\
BARI Gom 22 (Sufi) & 0.34 & - & 5.06 \\
BARI Gom 23 (Bijoy) & 11.06 & 6.00 & 2.03 \\
BARI Gom 24 (Prodip) & 41.03 & 39.00 & -1.55 \\
BARI Gom 25 & 4.45 & 6.00 & -0.57 \\
BARI Gom 26 & 11.43 & 12.00 & - \\
BARI Gom 27 & 1.09 & - & - \\
BARI Gom 28 & 0.72 & - & -1.53 \\
Others & 0.47 & 2.00 & - \\
\hline
\end{tabular}

Source: Expert elicitation workshop, 2014 \& BARI, 2012a.

\subsection{Variety wise quantities of foundation or breeder seed}

The public seed production system includes many organization i.e National Agricultural Research System (NARS), Bangladesh Agricultural Development 
Corporation (BADC), private seed company, NGO's, contract farmers and seed dealers. The crop research institutes of NARS are responsible for producing breeder seed of any crop variety which they developed and released. BADC multiplies the foundation seed from the breeder seed through its own seed producing farms. BADC multiplies foundation seed to certified seed and truthfully label seed (TLS) through their own seed multiplication farms or through contract farmers. BADC purchased seed from the contract grower and sell it to the farmers through the licensed seed dealers, and NGOs. Private seed companies also multiply foundation seed to truthfully label seed and sell those to the farmers.

The Table 3.7 presented amount of seed production in the year 2013-14 and 4 yrs (2009-13) average amount of seed production by the BADC (Table 3.8). Highest amount of certified and TLS seed $(21041.15 \mathrm{mt})(84 \%)$ of BARI Gom 24 (Prodip) was produced by BADC which covered $84 \%$ of total seed production in the year 2013-14 FY. This indicated that Prodip had higher demand among the farmers in the year 2013-14 and it was followed by BARI Gom 23 (1571.45 mt) and BARI Gom $26(859.02 \mathrm{mt})$. The certified and TLS seed production trend line (Fig. 4) showed that seed production of BARI Gom (Prodip) increased over the period 2009-14. On the other hand, seed production of BARI Gom 21 (Shatabdi) reduced gradually. Very minor change is observed in production of BARI Gom 23 (Bijoy).

Table 3.7. Seed production by the BADC according to various wheat variety

\begin{tabular}{|c|c|c|c|c|c|c|}
\hline \multirow{2}{*}{ Variety name } & \multicolumn{2}{|c|}{ Breeder seed (MT) } & \multicolumn{2}{|c|}{$\begin{array}{l}\text { Foundation seed } \\
(\mathrm{MT})\end{array}$} & \multicolumn{2}{|c|}{$\begin{array}{c}\text { Certified \& TLS seed } \\
\text { (MT) }\end{array}$} \\
\hline & $\begin{array}{l}2009-13 \\
(\text { avg) }\end{array}$ & 2013-14 & $\begin{array}{l}2009-13 \\
(\operatorname{avg})\end{array}$ & 2013-14 & $\begin{array}{l}2009-13 \\
\text { (avg) }\end{array}$ & 2013-14 \\
\hline BARI Gom 19 (Sourav) & - & - & - & - & 219.28 & - \\
\hline BARI Gom 20 (Gourav) & - & - & - & - & 277.16 & - \\
\hline $\begin{array}{l}\text { BARI Gom } 21 \\
\text { (Shatabdi) }\end{array}$ & 67.98 & - & 589.88 & - & 9535.04 & 776.08 \\
\hline BARI Gom 23 (Bijoy) & 67.15 & - & 233.89 & 124.75 & 1480.52 & 1571.45 \\
\hline BARI Gom 24 (Prodip) & 171.84 & - & 815.52 & 940.71 & 10564.91 & 21042.15 \\
\hline BARI Gom 25 & 47.42 & 223 & 45.03 & 386.9 & 256.60 & 663.91 \\
\hline BARI Gom 26 & 50.18 & 346.53 & 54.63 & 273.92 & 326.69 & 859.02 \\
\hline Total Seed production & 404.58 & 569.63 & 1738.95 & 1726.28 & 22660.21 & 24912.60 \\
\hline
\end{tabular}

Source: BADC, 2014. 


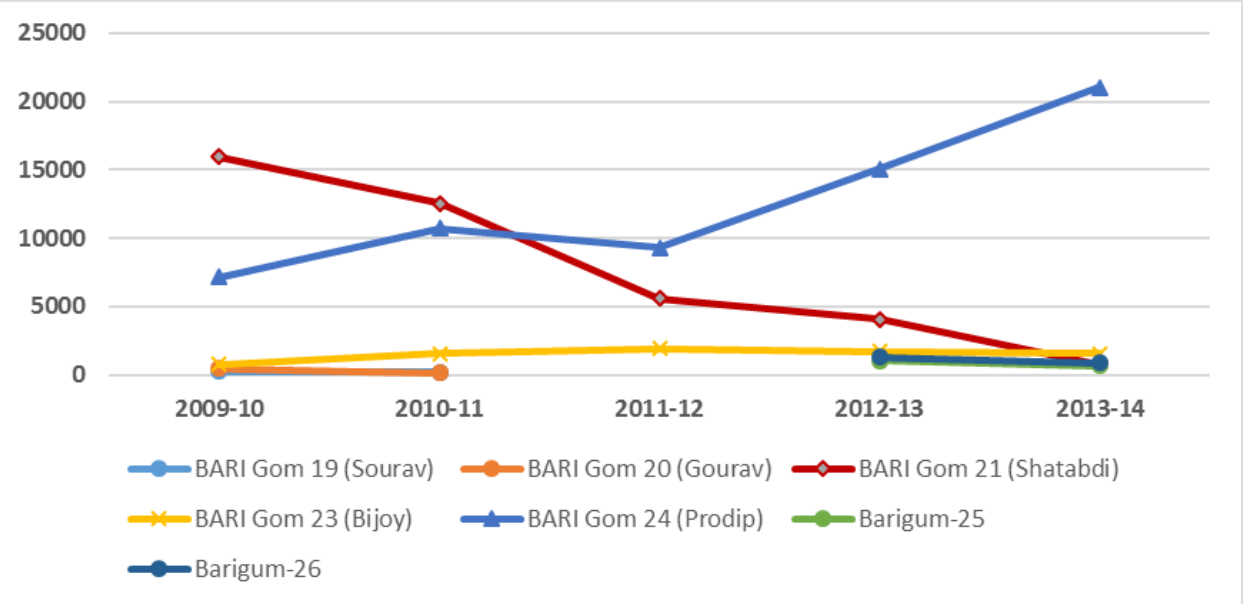

Fig. 4. Trend of seed production in the period 2010-14.

\subsection{Varieties attributes}

Farmers adopted wheat varieties due to some favorable varietal attributes. Different varieties have many type of different attributes. The experts in EE workshop explained the major reason behind adoption of any specific variety through identifying their main attributes. The major varietal attributes that attracted wheat farmers were mostly high yielder, bold and larger grain, short duration, tolerance to terminal heat stress and lodging. The early maturity, tolerant to salinity, and high yielding attributes of BARI Gom 25 were attracted by the farmers which leaded to a significant adoption level. BARI Gom 26 is well adopted due to its heat tolerant, short duration and disease resistant attributes. BARI Gom 27 and BARI Gom 28 are in increasing trend due to its special attributes like disease resistant to leaf and stem rust and also heat tolerant, and high yield.

\subsection{Reasons for popular varieties were phasing}

There are many varieties which have phased out from the farmer's field. Varieties were phased out due to releasing new wheat varieties by the researcher and adopting by the farmers. The new varieties are better than old varieties considering higher yield, tolerance to terminal heat stress and lodging, easy seed production and storage, tolerant to leaf rust disease and change in consumption preferences.

\section{Conclusion and Recommendations}

Many varieties have been developed by WRC but in details of varietal information and adoption information database was not developed which is very 
important and valuable for the scientist and policy planner. This study through expert elicitation for constructing detail varietal development and adoption database is timely and necessary for the research institute. The information provided through this study would help the breeder for improving variety considering reason of non-adoption by the farmers. This valuable information will also help the government and donor agencies in investing more on wheat improvement programs in Bangladesh.

From all over the Bangladesh 14 experts was invited to share their valuable knowledge and experience on wheat cultivation and adoption in the country. The average experience of the experts on wheat adoption was $22.65 \mathrm{yrs}$.

The number of total variety released in the Bangladesh was 40 in the period 1965-2014 and highest number of variety released in the period 1996-2000. Very recently, the WRC of BARI developed and released 6 improved varieties from 2010 to till now. In development process of modern varieties WRC of NARS shared $85 \%$ of linkage and CGIAR shared $47.5 \%$ of linkage. Number of released variety linked with CGIAR was highest in the period 1971-1975 and NARS also had linkage in highest number of released variety on the same period.

The wheat expert informed that 13 major varieties are adopted by the farmers in the recent years. Among those varieties, BARI Gom 24 (Prodip) covered highest cultivated area (186026 ha) which shared $41.03 \%$ of total wheat cultivated area. BARI Gom 21 (Shatabdi), BARI Gom 26 and BARI Gom 23 (Bijoy) ranked $2^{\text {nd }}$, $3^{\text {rd }}$ and $4^{\text {th }}$ position according to the share of cultivated area covered. There is a very minor difference between the expert opinion and published information about percentage of area adopted for wheat cultivation.

The seed production information showed that BADC the only wheat seed producer supplied $24912.60 \mathrm{mt}$ of wheat seed in the year 2013-14. The trend of seed production by different wheat variety revealed that over the period 2010-14, the seed production of BARI Gom 24 (Prodip) increased and BARI Gom 21 (Shatabdi) decreased. Increased seed production trend of Prodip variety leaded to highest adopted area of that variety. The main reason behind highest adopted area of Prodip variety was it's very attractive attributes like high yield, big spike, large grain and lodging tolerance character. Although the Prodip covered highest area but other newly developed variety like BARI Gom 25, BARI Gom 26, BARI Gom 27 and BARI Gom 28 were the most promising varieties which showed increasing adoption path among the expert. These varieties have very good potentiality due to having short duration, tolerance to terminal heat stress, tolerant to salinity and lodging attributes.

Satisfying higher demand for wheat consumption and ensuring food security through providing alternative to rice are the major concerning issue of the policy planner and the scientist. Although many high yielding promising varieties were 
developed through devoted effort of scientist of Bangladesh, but due to lack of proper planning and implementation the adoption rate of those varieties are very low and speed of adoption are slow. Effective planning to increase seed production and extension are the most important and demanding issue for increasing area adoption and production of high yielding wheat varieties thus consequently ensure food security through increase consumption and reduce import dependency on wheat.

\section{References}

Alamgir M. Famine in South Asia: political economy of mass starvation. Vol. XVIII. Cambridge, MA: Oelgeschlager, Gunn \& Hain; 1980. 420 pp.

Banglapedia. 2006. BANGLAPEDIA - national encyclopedia of Bangladesh http://www.banglapedia.org/httpdocs/HT/W_0053.htm 2 November 2012.

BADC (Bangladesh Agricultural Development Corporation) 2014. http://www.badc.gov.bd

BARI (Bangladesh Agricultural Research Institute). 2010. Wheat production in Bangladesh: a success story http://www.bari.gov.bd/index.php?option=com simplestforum \&view=postlist $\&$ topic $=$ true $\&$ forumId $=1 \&$ parent $I d=288 \quad 4$ November 2012.

BARI (Bangladesh Agricultural Research Institute). 2012a. Wheat varieties released by Bangladesh Agricultural Research Institute http://www.bari.gov.bd/index.php?option=com_advancedsearch\&view=adva ncedsearch\&id=861,862,863,\&page_no=0 4 November 2012.

BARI (Bangladesh Agricultural Research Institute). 2012b. Year of release and average yield of Bangladesh wheat varieties developed since 1974. http://webcache.googleusercontent.com/search?q=cache:iWtyqODXrskJ:ww w.bari.gov.bd/index.php\%3Foption\%3Dcom_simplestforum\%26view\%3Dp ostlist\%26topic\%3Dtrue\%26forumId\%3D1\%26parentId\%3D852+\&cd=1\&h $\mathrm{l}=\mathrm{en} \& \mathrm{ct}=\mathrm{clnk}$ (4 November 2012.

BBS. 2010. Household Income and Expenditure Survey, Bangladesh Bureau of Statistics.

BBS. 2011. Statistical year book of Bangladesh-2011. Bangladesh Bureau of Statistics, Planning Division, Ministry of Planning, Government of the People's Republic of Bangladesh www.bbs.gov.bd 4 November 2012.

Index Mundi. 2012a. Bangladesh milled rice production by year: market year, production (1000MT) and growth rate (\%) http://www.indexmundi.com/ agriculture/?country=bd\&commodity=milled-rice $\&$ graph=production 4 November 2012.

Index Mundi. 2012b. Bangladesh wheat production by year: market year, production (1000MT) and growth rate (\%) http://www.indexmundi.com/ agriculture/?country=bd\&commodity=wheat $\&$ graph=production 4 November 2012. 
O'Brien D. 2011. World wheat market supply-demand trends http://www.agmanager.info/marketing/outlook/newletters/archives/GRAINOUTLOOK_03-04-11.pdf 4 November 2012.

Pandit D. B, Mandal, M. S. N., Hakim, M. A., Barma, N. C. D., Tiwari, T. P., Joshi, A. K. (2011) Farmers' preference and informal seed dissemination of first Ug99 tolerant wheat variety in Bangladesh. Czech Journal of Genetics and Plant Breeding 2011; 47 (Special Issue):S160-S164.

WRC. 2014. Progress report of the project CSISA objective 4 (Wheat), Wheat Research Center, Report presented at at Kathmandu, Nepal, 11-12 Sept. 2014.

WRC (Wheat Research Center). 2009. Annual Report, 2008-09. Nashipur, Dinajpur, Bangladesh. $181 \mathrm{P}$. 